\title{
Microplastics distribution and characterization in epipsammic sediments of tropical Atlantic Ocean, Nigeria
}

\author{
Omowunmi H. Fred-Ahmadu ${ }^{a}$, Olusegun O. Ayejuyo ${ }^{\mathrm{b}}$, Nsikak U. Benson ${ }^{\mathrm{a}, *}$ \\ a Department of Chemistry, Covenant University, Km 10 Idiroko Road, Ota, Nigeria \\ ${ }^{\mathrm{b}}$ Department of Chemistry, University of Lagos, Akoka, Nigeria
}

\section{A R T I C L E I N F O}

\section{Article history:}

Received 3 February 2020

Received in revised form 23 April 2020

Accepted 15 July 2020

Available online 18 July 2020

\section{Keywords:}

Microplastic pollution

Tidal waterline

Hydrodynamic conditions

Gulf of Guinea

Fragments

ATR-FTIR

\begin{abstract}
A B S T R A C T
Recent reports indicate that microplastics (MPs) show both temporal and spatial variations therefore, regional data collection and environmental dynamics are vital aspects of understanding the underlying sources and factors that influence the abundance and dispersion of the plastic particles. This paper presents a baseline report on the abundance of microplastics across three tidal waterlines (high, drift and current) of the tropical Atlantic ecosystem. Microplastics (1 - $5 \mathrm{~mm}$ ) occurrence and distribution in epipsammic sediments of five beaches in Lagos, Nigeria (Gulf of Guinea) were assessed. The microplastics were extracted by density flotation using saturated solution of $\mathrm{NaCl}$ and the identification of polymer types was done by attenuated total reflectance Fourier transform infra-red spectroscopy, ATR-FTIR. Results showed significant variations in the population of MPs in the three tidal waterlines with the high and drift waterlines accounting for $58.83 \%$ and $41.16 \%$ of the total MPs, respectively while no MPs were detected in the current waterline sediment. Polyethylene, polystyrene and polypropylene were the most abundant polymers recorded. Fragments were predominantly detected and preproduction pellets formed only $5.27 \%$ of total microplastics. Polymer risk index calculations showed low to medium risk of the microplastics found and local hydrodynamic conditions such as Ocean surges and current intensity were observed to influence the distribution and dispersion of microplastics. Continuous monitoring of MPs abundance is necessary to minimize the polymers' risk to the ecosystem. (C) 2020 Elsevier B.V. All rights reserved.
\end{abstract}

\section{Introduction}

Microplastic pollution has gained increasing global attention due to the potential threat to both terrestrial and aquatic life. Microplastics (MPs) are manufactured directly in sizes $<5 \mathrm{~mm}$ in diameter (primary microplastics) or formed as a result of the fragmentation of larger plastics due to environmental exposure and abrasion (secondary microplastics) (Fred-Ahmadu et al., 2020; Thompson, 2016). The most commonly identified plastic polymers in environmental samples are polyethylene (PE), polypropylene (PP), polystyrene (PS) and polyvinylchloride (PVC) (GESAMP, 2015; Ogata et al., 2009). Some of the sources of microplastics in the aquatic ecosystem include loss of pellets during transportation, wastewater effluent, fishing ropes and gears, cigarette butts, abrasion from sandblasting at shipyards, plastic waste carried by wind or run-off water, and so on (Rochman, 2013). Plastic wastes are generally non-biodegradable, persistent and pervasive in the environment. While many beaches are regularly cleaned to increase their face value and attract tourists, the cleaning rarely takes care of microplastic particles. Sandy

\footnotetext{
* Corresponding author.

E-mail address: nsikak.benson@cu.edu.ng (N.U. Benson).
}

beaches, therefore, become sinks for micro-sized plastics and other kinds of debris.

Microplastics are regarded as multiple stressors of the aquatic ecosystem because they present considerable risks in various ways: (a) by direct toxicity posed by plastics particles causing oxidative stress, inflammation and cell damage in organisms, (b) chemical toxicity due to the effects of additives such as plasticizers, biocides, flame retardants and UV stabilizers which may contain toxic trace metals, (c) as vectors of pathogens and parasites like Escherichia coli; and (d) as vectors of persistent organic pollutants (POPs) including phthalate esters (Benson and Fred-Ahmadu, 2020; Zhang et al., 2019; Li et al., 2017; Vethaak and Leslie, 2016; Leslie and Vethaak, 2014). In addition, spatial and temporal variations do occur with field sampled microplastics in terms of their abundance, types, shapes, colour and the distribution and limited studies are available on the distribution of microplastics along depositional lines of beaches. Here, this study presents a snapshot and baseline data of the abundance, types and variations of microplastics in five sandy beaches, namely Badagry (BG), Oniru (OR), Elegushi (EG), Atican (AC) and Eleko (EK). Our aim was to study the depositional variations of microplastics along the coastline of the tropical Atlantic ecosystem, Nigeria and to evaluate the influence of local hydrodynamic 
conditions such as ocean current intensity and surges on the spatial distribution of microplastics. To our knowledge, this is the first study to investigate the abundance and distribution of microplastics contamination in beach sediments of the Gulf of Guinea, off the Coast of Nigeria.

\section{Materials and methods}

\subsection{Study areas}

The study locations are strategically located in the northeast part of the tropical Atlantic Ocean. The Gulf of Guinea is an important oceanographic ecosystem found along the northeasternmost part of the tropical Atlantic Ocean. The Nigeria marine area is part of the Gulf of Guinea, a coastline that stretches a distance of about $853 \mathrm{~km}$ from the Cross River estuary at the east coast of the country to Badagry beach in the west. The beaches designated for sampling were Badagry (BG), Oniru (OR), Elegushi (EG), Atican (AC) and Eleko (EK). The coastal areas in general experience a tropical wet climatic period (April to October) with annual mean temperatures between 25 and $28{ }^{\circ} \mathrm{C}$, and dry climate (November to March) conditions with mean temperatures of about 29 to $32{ }^{\circ} \mathrm{C}$ (Benson and Fred-Ahmadu, 2020; Benson et al., 2015; Awosika and Folorunsho, 2006; French et al., 1995). Along the coastline, there are pronounced proliferation of human activities including industries, urban settlements, fishing, recreation, tourism, trading and religious rites. These have contributed significantly to the unregulated discharge of industrial effluents, domestic and agricultural wastes onto the shores and aquatic ecosystems located along the coastline (Benson et al., 2014; Benson, 2010a,b). It was observed during the sampling campaign that beaches like Badagry, Oniru and Atican appeared clean while Elegushi and Eleko beaches had significantly high deposits of debris above and along the high waterlines. The coordinates of each sampling location on the coast were recorded using a handheld Garmin ${ }^{\circledR}$ Global Positioning System (GPS) device. The locations were between 6.2 and $6.7 \mathrm{~m}$ above the sea level. The high waterline was about $5 \mathrm{~m}$ away from the drift line. The map of the study area is presented in Fig. 1, while details of the sampling location coordinates are presented in Tables S1a-b.

\subsection{Microplastics sampling}

The sampling was carried out between July, 2018 and August 2019. Ten sampling locations along each macrotidal psammitic beach was established about $100 \mathrm{~m}$ apart from each other, covering about $1 \mathrm{~km}$ stretch of each beach coast line (Table S1). Ten sediment samples were collected from three (3) transects at each beach covering: (i) The high waterline, the point that represents the maximum rise of the ocean water. It is typically composed of dry sediment and debris left by the high tide (ii) the drift line, the intersection of land with the ocean water where the water fluctuates, changing with the tide or other fluctuations in the water and (iii) the current waterline, the intersection of the land with the water surface at an elevation of low water (National Oceanic and Atmospheric Administration, 2016). Surface sediment were collected from the high waterline and drift line by placing a quadrat $(0.5 \times 0.5 \times 0.2 \mathrm{~m})$ on the ground and $\mathrm{a}$ stainless steel spoon was used to scoop the beach sand to $2 \mathrm{~cm}$ depth while the current waterline sediment was scooped directly into Ziploc bags (without the use of the quadrat) due to ocean surges. Large identifiable organic materials within the quadrat were removed by handpicking. Thirty (30) sediment samples were collected from each beach making a total of one hundred and fifty (150) sediment samples from the five beaches. The representative surface sediment samples collected were carefully
Table 1

Number of MPs found along transects and sampling locations.

\begin{tabular}{|c|c|c|c|c|c|}
\hline Sample code & Badagry & Oniru & Elegushi & Atican & Eleko \\
\hline $1 \mathrm{H}$ & 1 & 98 & 58 & 28 & 21 \\
\hline $1 \mathrm{D}$ & 0 & 67 & 30 & 1 & 20 \\
\hline $1 \mathrm{C}$ & 0 & 0 & 0 & 0 & 0 \\
\hline $2 \mathrm{H}$ & 0 & 82 & 78 & 25 & 18 \\
\hline $2 \mathrm{D}$ & 4 & 63 & 10 & 0 & 8 \\
\hline $2 C$ & 0 & 0 & 0 & 0 & 0 \\
\hline $3 \mathrm{H}$ & 6 & 105 & 109 & 43 & 14 \\
\hline $3 \mathrm{D}$ & 4 & 80 & 25 & 0 & 10 \\
\hline $3 C$ & 0 & 0 & 0 & 0 & 0 \\
\hline $4 \mathrm{H}$ & 0 & 79 & 123 & 5 & 13 \\
\hline $4 \mathrm{D}$ & 0 & 87 & 59 & 12 & 11 \\
\hline $4 C$ & 0 & 0 & 0 & 0 & 0 \\
\hline $5 \mathrm{H}$ & 4 & 91 & 87 & 18 & 18 \\
\hline $5 \mathrm{D}$ & 0 & 93 & 75 & 2 & 11 \\
\hline $5 C$ & 0 & 0 & 0 & 0 & 0 \\
\hline $6 \mathrm{H}$ & 5 & 46 & 123 & 15 & 11 \\
\hline $6 \mathrm{D}$ & 4 & 106 & 44 & 1 & 9 \\
\hline $6 C$ & 0 & 0 & 0 & 0 & 0 \\
\hline $7 \mathrm{H}$ & 2 & 65 & 61 & 12 & 15 \\
\hline 7D & 0 & 82 & 16 & 2 & 10 \\
\hline $7 C$ & 0 & 0 & 0 & 0 & 0 \\
\hline $8 \mathrm{H}$ & 5 & 88 & 78 & 13 & 5 \\
\hline $8 D$ & 0 & 122 & 16 & 14 & 5 \\
\hline $8 C$ & 0 & 0 & 0 & 0 & 0 \\
\hline $9 \mathrm{H}$ & 0 & 81 & 68 & 17 & 14 \\
\hline 9D & 1 & 107 & 27 & 9 & 12 \\
\hline $9 \mathrm{C}$ & 0 & 0 & 0 & 0 & 0 \\
\hline $10 \mathrm{H}$ & 0 & 97 & 74 & 11 & 5 \\
\hline $10 \mathrm{D}$ & 0 & 91 & 35 & 0 & 4 \\
\hline $10 C$ & 0 & 0 & 0 & 0 & 0 \\
\hline Total & 36 & 1730 & 1196 & 228 & 234 \\
\hline
\end{tabular}

$\mathrm{H}=$ high waterline; $\mathrm{D}=$ drift waterline; $\mathrm{C}=$ current waterline.

wrapped in aluminium foil, labelled and stored in clean Ziploc ${ }^{\circledR}$ bags before transportation to the laboratory. Each sediment sample was air dried and sieved using stainless steel sieves with mesh sizes $5 \mathrm{~mm}, 3 \mathrm{~mm}$ and $1 \mathrm{~mm}$. Plastics retained on the $5 \mathrm{~mm}$ sieve were separated as meso- and macroplastics while those retained on $3 \mathrm{~mm}$ and $1 \mathrm{~mm}$ sieves were considered for further processing as microplastics.

\subsection{Extraction of plastics from sediment samples}

Saturated solution of $\mathrm{NaCl}$ was prepared by dissolving $358.9 \mathrm{~g}$ of $\mathrm{NaCl}$ in $1 \mathrm{~L}$ of distilled water (Bosker et al., 2018) and filtered into pre-cleaned glass jars. Dried sediment $(1 \mathrm{~kg})$ was weighed for each sample into a clean glass jar and flushed with $500 \mathrm{~mL}$ of saturated $\mathrm{NaCl}$ solution in two portions of $500 \mathrm{~g}$. The mixture was thoroughly mixed using a steel rod and then placed on an orbital shaker and agitated at $300 \mathrm{rpm}$ for $15 \mathrm{~min}$. The mixture was allowed to settle for about $1 \mathrm{~h}$ after which the supernatant was filtered using a $1 \mathrm{~mm}$ stainless steel sieve. The extraction for each sediment was performed at least thrice. The residue retained on the sieve was rinsed with distilled water and air-dried in clean fume hoods after which it was wrapped in aluminium foil to prevent contamination.

\subsection{Visual and instrumental identification of beach microplastics}

The dried residue was placed in a clean transparent petri dish and viewed under a stereo microscope (BMS 74957, WF $10 \times 22)$ at $\times 40$ magnification to identify the microplastic particles (Thompson, 2016). The MPs were separated from organic material using a stainless steel tweezer. Visual identification under the dissecting microscope was done three times per sample on different days, to ensure that all plastic-like particles and fibres were identified and picked out of the residue. After visual 


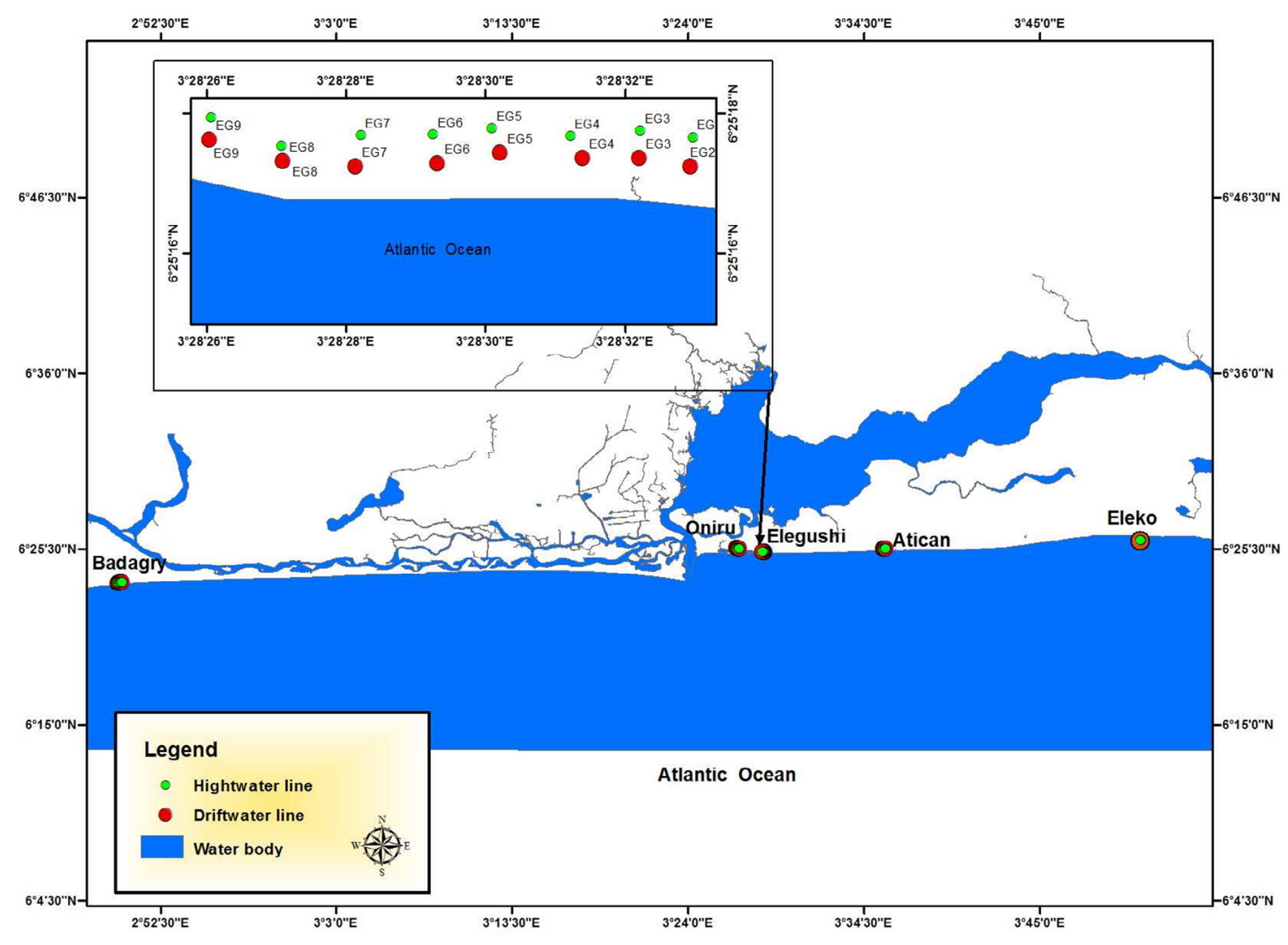

Fig. 1. Map of the tropical Atlantic Ocean showing portions of the sampling sites.

identification with the microscope, ninety (90) particles that were representative of all kinds of MPs collected were pooled together and characterized into polymer types using Attenuated Total Reflectance Fourier Transform Infra-Red (PerkinElmer ATR-FTIR Diamond Spectrum 2, C1232) (Hüffer et al., 2018) at the University of Newcastle, Australia, and Agilent 630 Cary FTIR Spectrometer equipped with Diamond attenuated total reflectance (ATR) system in Covenant University, Nigeria. All spectra were recorded at $4 \mathrm{~cm}^{-1}$ and $8 \mathrm{~cm}^{-1}$ resolution and measurements ranged from $4000-500 \mathrm{~cm}^{-1}$ and $4000-650 \mathrm{~cm}^{-1}$, respectively. The hit quality index for all accepted materials in the synthetic fibres ATR library (2004 Bruker optik GmbH) was 700 but $<1000$ (Thompson et al., 2004). Other materials were regarded to have failed the ATR-FTIR test hence classified as non-plastic. Furthermore, the absorption bands of each polymer were studied and matched with Agilent polymer handheld ATR library with acceptable match quality set at $\geq 70 \%$ and further confirmed using validated polymer spectral data reported in literature by Jung et al. (2018). Only five (5) items were confirmed to be non-plastic materials. The non-plastic items identified were charcoal (2), textile fabric (1), and shell fragments (2). Fig. 2 shows the abundance of MP polymers found in the sediment samples collected from Badagry, Oniru, Elegushi, Atican, and Eleko beaches in the tropical Atlantic ecosystem, Lagos, Nigeria.

\subsection{Quality control and quality assessment}

Similar weights of sediments were analysed for each sediment and the volume of saturated $\mathrm{NaCl}$ was also kept at $500 \mathrm{~mL}$. To test the recovery of the method, larger plastic samples collected from the field (PE and PS) were cut into sizes $(<5 \mathrm{~mm}$ but $>1 \mathrm{~mm}$ ) using a stainless steel scissors and 20 pieces of the plastics were mixed with $1 \mathrm{~kg}$ of dried sediment collected from the three waterlines. These were subjected to the same extraction process and the recovery rates ranged from $95 \%-100 \%$. To reduce contamination, samples were always covered with aluminium foil and contact with plastic materials was avoided. Procedural blanks containing only saturated $\mathrm{NaCl}$ solution were also analysed along with samples and no significant contamination was recorded.

\section{Results and discussion}

3.1. Abundance of microplastics and the influence of local hydrodynamic conditions

A total of 4055 plastic items were separated from the beach sediments. Plastic items greater than $5 \mathrm{~mm}$ (meso- and macroplastics) made up $16 \%$ of the total plastics, with Badagry beach sediments having 38 pieces, Oniru (93), Elegushi (281), Atican (74) and Eleko (145). A total of 3424 particles $/ \mathrm{m}^{2}$ were identified as microplastics ( $1-5 \mathrm{~mm}$ ), and comprised $5 \%$ pellets, $33 \%$ foam fragments, $4 \%$ fibres and $58 \%$ hard fragments. In general, MPs are ubiquitous constituents of our coastal, terrestrial and marine environments, and in recent times, there is an increasing attention on MPs pollution limited in size to those that are $<5 \mathrm{~mm}$ owing to the health and ecological threats they pose (Fred-Ahmadu et al., 2020; Ramirez et al., 2019; Zhang et al., 2018; Arthur et al., 2009). The general trend in the abundance of total MPs in the various depositional waterlines was in the order of high $(\mathrm{HWL})>$ drift $(\mathrm{DWL})>$ current $(\mathrm{CWL})$ except for Oniru beach. The trend is in line with previous studies which reported greater abundance of marine debris and plastics in the high tidelines and beyond (Álvarez-Hernández et al., 2019; Constant et al., 2019; Holmes, 2013; Karthik et al., 2018). The depositional line marks are as a result of hydrodynamic conditions such as ocean surges, storms and current intensity (Constant et al., 
Table 2

Summary of microplastics abundance in the sampled beaches.

\begin{tabular}{|c|c|c|c|c|c|}
\hline Parameters & Badagry & Oniru & Elegushi & Atican & Eleko \\
\hline No. of high waterline MPs & 23 & 832 & 859 & 187 & 134 \\
\hline No. of drift waterline MPs & 13 & 898 & 337 & 41 & 100 \\
\hline No. of current waterline MPs & 0 & 0 & 0 & 0 & 0 \\
\hline No. of sediment samples & 30 & 30 & 30 & 30 & 30 \\
\hline Mass (g) of MPs collected & 0.79 & 10.78 & 12.62 & 3.45 & 3.11 \\
\hline Average no. of MPs $/ \mathrm{kg}$ of sediment & $3.6 \pm 3.5$ & $173.0 \pm 21.3$ & $119.6 \pm 38.5$ & $22.8 \pm 9.3$ & $23.4 \pm 9.2$ \\
\hline
\end{tabular}

Table 3

Recent similar studies showing microplastics count and polymer abundance characteristics.

\begin{tabular}{|c|c|c|c|c|c|c|}
\hline Country & Total MP count & Sediment type & Polymers & MP sizes & Sample points & Authors \\
\hline Nigeria & 3424 & Beach & $\mathrm{PE}>\mathrm{PS}>\mathrm{PP}$ & $1-5 \mathrm{~mm}$ & 150 & This study \\
\hline Spain & 324 & Beach & $\mathrm{PE}>\mathrm{PP}>\mathrm{PS}$ & $1-5 \mathrm{~mm}$ & 40 & Álvarez-Hernández et al. (2019) \\
\hline Slovenia & 26 & Beach & PE $>$ PET $>$ Nylon $6>\mathrm{PP}$ & $1-5 \mathrm{~mm}$ & 9 & Korez et al. (2019) \\
\hline Brazil & 5819 & Beach & Fibres & $2.5-5 \mathrm{~mm}$ & 4 & Martinelli Filho and Monteiro (2019) \\
\hline France & 7048 & Beach & $\begin{array}{l}\mathrm{PE}>\mathrm{PP}>\mathrm{PS}>\mathrm{PA}>\mathrm{PVC}> \\
\mathrm{PEVA}>\mathrm{PET}>\mathrm{PES}>\mathrm{PU}>\mathrm{A}\end{array}$ & $0.063-5 \mathrm{~mm}$ & 48 & Constant et al. (2019) \\
\hline Spain & 9149 & Beach & $\mathrm{PE}>\mathrm{PP}>\mathrm{PS}$ & $1-5 \mathrm{~mm}$ & 4 & Edo et al. (2019) \\
\hline India & 448 & Beach & $\begin{array}{l}\mathrm{PE}>\mathrm{PP}>\mathrm{PS}>\text { Nylon }>\text { PVC } \\
>\mathrm{PU}\end{array}$ & $0.3-5 \mathrm{~mm}$ & 25 & Karthik et al. (2018) \\
\hline Iran & 4265 & Beach & PE $>$ Nylon $>$ PET & $<5 \mathrm{~mm}$ & 5 & Naji et al. (2017) \\
\hline Hawaii & 44,988 & Beach & $\mathrm{PE}>\mathrm{PP}$ & $0.5-8 \mathrm{~mm}$ & 6 & Young and Elliott (2016) \\
\hline Taiwan & 1097 & Beach & $\mathrm{PE}>\mathrm{PP}>\mathrm{PS}>\mathrm{ABS}$ & $0.28-4 \mathrm{~mm}$ & 8 & Kunz et al. (2016) \\
\hline
\end{tabular}

Poly(ethylene vinyl acetate) (PEVA), polyester (PES), acrylic (A).

2019). In contrast to the general trend, Oniru beach recorded lower microplastic particles in the HWL than that of the DWL as depicted in Table 2. This could be attributed to the observed lower Ocean current intensity compared to other beaches. The low current intensity was due to the presence of boulders of rock which were positioned at about one kilometre into the sea to dissipate large sea waves, causing only gentle currents to reach the shoreline. The microplastics and other particles were visibly seen being deposited on the drift waterline. Another factor that may be responsible for the less abundance of MPs in the high waterline was beach cleaning. Oniru beach was one of the cleanest of the beaches sampled. For the other four beaches, there were no obstructions on the path of the sea waves; the Ocean current intensity was higher and the natural large waves reached the shorelines. Generally, the high waterline accounted for $58.83 \%$ of the total MPs count and the drift waterline formed 41.16\%. Microplastics were not detected in any of the sediment samples collected from the current waterline. This study further highlights the important influence of hydrodynamic conditions such as ocean current intensity and tidal lines on the spatial distribution of sediments, and by implication the quantity of microplastics in sediments. These beaches are characterized by mesotidal waves and wind-driven waves, which are predominantly produced by south-westerly winds (Smith, 1959; Asuquo and Oghenechovwen, 2019). The number of recovered microplastics across the three transects (high, drift and current waterlines) for each of the beaches at ten locations varied significantly as presented in Table 1 . Table 2 shows the summary of abundance and masses of microplastics collected from the beaches.

\subsection{Description of microplastics}

The beach plastics showed variations in types, colours and shapes. Pieces of fibre, ropes, pellets and fragmented plastics were identified. The results from the ATR-FTIR showed the presence of PE, PP, PVC (polyvinyl chloride), PA (polyamide), PS, PU (polyurethane), EVA (ethylene vinyl acetate), ABS (acrylonitrile butadiene styrene), and PET (polyethylene terephthalate). Some of the plastic materials occurred as mixture of PE and PP. The colours observed were white, pink, green, black, blue, clear (transparent) and yellow. The observed trend for MPs polymer abundance was $\mathrm{PE}>\mathrm{PP}>\mathrm{PS}$ for Badagry, Oniru and Eleko beaches, PE $>$ PS $>$ PP for Elegushi and PS $>$ PE $>$ PP for Atican beach. Generally, the sampled MP particles were dominated by PE, followed by PS and PP as shown in Fig. 2. A similar study of Canary Island beaches reported the abundance of the polymers in a slightly different order, PE > PP > PS (Álvarez-Hernández et al., 2019). Polyethylene terephthalate, ethylene vinyl acetate, polyvinyl chloride, polyamide-66, polyurethane, and latex accounted for other polymer types detected. Additionally, the MPs were separated and categorized based on the nature of their physical types, shape, colour, size, and appearance. The polymeric classifications observed for all MPs across all sites were foam plastic fragments, hard fragments, pellets, plastic strands and fibres. The summarized categories are presented in Fig. 3, which clearly shows that the foam and hard plastic fragments were the dominant plastics across all sites.

Fragments of hard plastics and foams were more prevalent than pellets and fibres as similarly reported in studies from different parts of the world (Álvarez-Hernández et al., 2019; Karthik et al., 2018; Young and Elliott, 2016). However, some other studies have reported the prevalence of fibres (Constant et al., 2019; Martinelli Filho and Monteiro, 2019) and pellets (Antunes et al., 2018 ) in some sandy beaches.

\subsection{Sources of microplastics}

The accurate prediction of the sources of microplastics in the sediment is difficult since some of the plastics may have been transported over long distances and carried by sea currents to the location where they are found (Law and Thompson, 2014). There was no indication of plastic production around any of the sampling stations. However, potential sources may include waste plastic bags, disposable plastic bottles, food packs and straws left by tourists and food vendors along the coast that have fragmented over time. Fishing activities may be responsible for the presence of plastic ropes and net fragments.

A comparison of the results from this study with other studies of beach surface sediments shows some similarities as well as variations. The most common trend of polymer abundance as observed in Table 3 is PE $>$ PP $>$ PS which is similar to trends for beaches in the present study except for Elegushi and Atican 


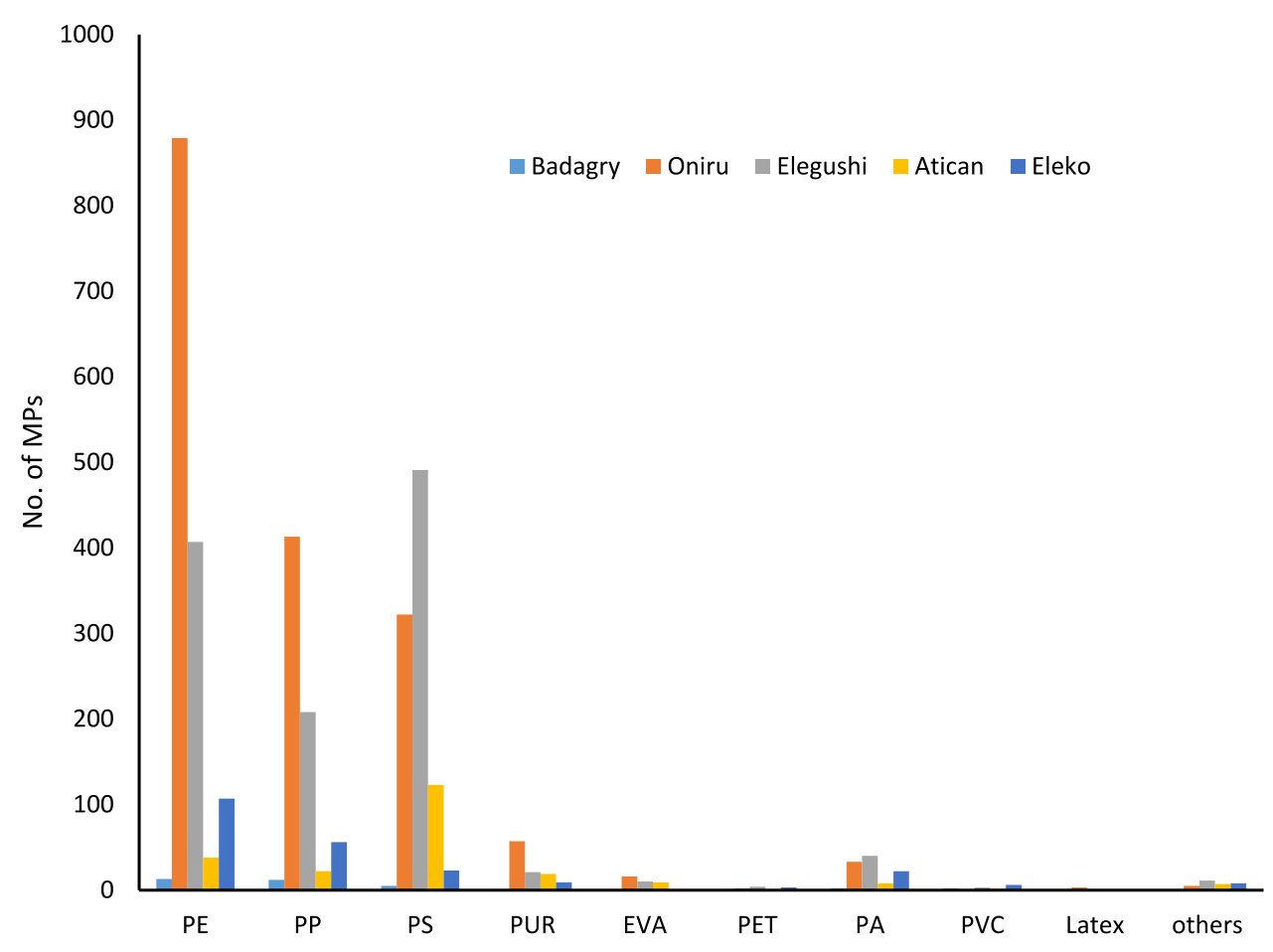

Fig. 2. Relative abundance of microplastic polymers in the beach sediments. (For interpretation of the references to colour in this figure legend, the reader is referred to the web version of this article.)

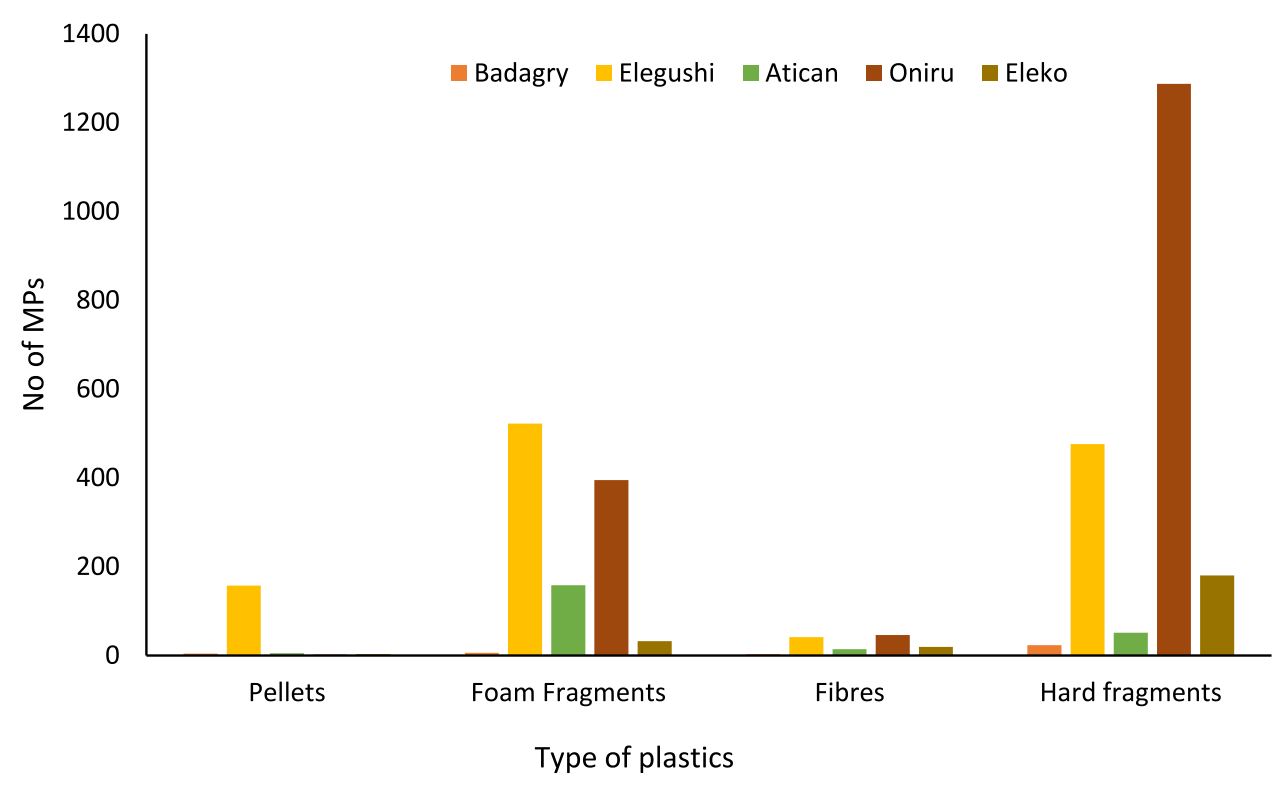

Fig. 3. Relative abundance of plastic types found in sediments across all beaches.

beaches. This polymer trend was also observed by Ogata et al. (2009). This implies that PE, PP and PS products such as plastic bags, plastic films, containers and plastic food packaging are major contributors to microplastic debris and this lends credence to the ban or reduction in the production and use of single-use plastic items.

Table 3 indicates that there is no correlation between the number of sample points and the abundance of microplastics. These variations make it plausible to consider data gathering from different locations and to proffer specific and local solutions to the microplastics problem while working within the global framework.

\subsection{Polymer risk index}

The possible ecological harm of microplastics was assessed by calculating the polymer risk index (Xu et al., 2018a,b) based on the polymer hazard scores developed by Lithner et al. (2011). The polymer risk index $(\mathrm{H})$ is given by

$\mathrm{H}=\sum \mathrm{P}_{\mathrm{n}} \times \mathrm{S}_{\mathrm{n}}$

where $P_{n}$ is the percentage of MP type collected at each sample station and $S_{n}$ is the hazard score. The hazard risk classification and hazard scores of polymers are indicated in Tables S2 and S3, respectively. The calculated polymer hazard risk $(\mathrm{H})$ of the beach microplastics polymers are presented in Table 4 . 
Table 4

Hazard risk index of beach microplastics.

\begin{tabular}{lllllllll}
\hline & PE & PP & PS & PUR & EVA & PET & PA & PVC \\
\hline Badagry & 3.97 & 0.33 & 4.17 & 205.11 & 0.00 & 0.11 & 3.50 & 586.17 \\
Oniru & 5.59 & 0.24 & 5.58 & 243.29 & 0.08 & 0.00 & 1.38 & 0.00 \\
Elegushi & 3.74 & 0.17 & 12.32 & 129.65 & 0.08 & 0.01 & 2.69 & 26.47 \\
Atican & 1.83 & 0.10 & 17.11 & 615.33 & 0.36 & 0.00 & 2.21 & 92.55 \\
Eleko & 3.15 & 0.20 & 2.95 & 284.00 & 0.00 & 0.19 & 19.38 & 270.54
\end{tabular}

The hazard index results indicate category I risk level for PE, PP, EVA, PET and PA in all the beaches except for PA in Eleko beach with risk level II. PS and PVC in Elegushi and Atican beaches also record level II risk. PUR showed level III risk in all the beaches while PVC recorded level III risk in Badagry and Eleko beaches. Risk level III was most prevalent in the assessment of MPs from estuarine surface water in China (Xu et al., 2018a,b).

\section{Conclusion}

The psammitic sediments of Badagry, Oniru, Elegushi, Atican and Eleko beaches, Lagos, Nigeria was surveyed for the first time for microplastics range $1-5 \mathrm{~mm}$. Significant variations in the abundance of microplastics along the depositional lines was observed. The high waterline showed higher abundance of MPs than the drift waterlines and no MPs were detected in the current waterline. There were indications that local hydrodynamic conditions such as wind-driven waves and current intensity influenced the distribution and deposition of the MP particles. Fragments were more dominant than fibres and pellets. Furthermore, the high waterline accounted for $58.84 \%$ of the microplastics in the three tidal zones sampled. Based on comparison with other similar studies, regional data collection is vital to addressing the marine microplastic pollution issue.

\section{CRediT authorship contribution statement}

Omowunmi H. Fred-Ahmadu: Conceptualization, Data curation, Formal analysis, Investigation, Writing - review \& editing. Olusegun 0. Ayejuyo: Conceptualization, Supervision, Writing original draft, Writing - review \& editing. Nsikak U. Benson: Conceptualization, Data curation, Formal analysis, Investigation, Supervision, Writing - original draft, Writing - review \& editing.

\section{Declaration of competing interest}

The authors declare that they have no known competing financial interests or personal relationships that could have appeared to influence the work reported in this paper.

\section{Acknowledgements}

The authors wish to acknowledge the financial support from Covenant University and the Association of Commonwealth Universities Blue Charter Fellowship, U.K. We also acknowledge the University of Newcastle, Australia for analytical instrumentation support.

\section{Funding}

This research was financially supported by Covenant University, Ota, Nigeria through Covenant University Seed Grant.

\section{Appendix A. Supplementary data}

Supplementary material related to this article can be found online at https://doi.org/10.1016/j.rsma.2020.101365.

\section{References}

Álvarez-Hernández, C., Cairós, C., López-Darias, J., Mazzetti, E., HernándezSánchez, C., González-Sálamo, J., Hernández-Borges, J., 2019. Microplastic debris in beaches of Tenerife (Canary Islands, Spain). Mar. Pollut. Bull. 146, 26-32. http://dx.doi.org/10.1016/j.marpolbul.2019.05.064.

Antunes, J., Frias, J., Sobral, P., 2018. Microplastics on the portuguese coast. Mar Pollut. Bull. 131, 294-302. http://dx.doi.org/10.1016/j.marpolbul.2018.04.025.

Arthur, C., Baker, J., Bamford, H., 2009. Proceedings of the International Research Workshop on the Occurrence, Effects and Fate of Microplastic Marine Debris. NOAA Technical Memorandum NOS-OR \& R-3, Sept. 9-11, 2008.

Asuquo, F.E., Oghenechovwen, O.C., 2019. Detection and spatio-temporal variation of marine heatwaves in the Gulf of Guinea, Nigeria. J. Oceanogr. Mar Res. 10, 11-21. http://dx.doi.org/10.5897/JOMS2019.0152.

Awosika, L.F., Folorunsho, R., 2006. Climate change and impact on the coastal environment of Nigeria. In: Ivbijaro, M.F., Akintola, F., Okechukwu, R.U. (Eds.), Sustainable Environmental Management in Nigeria. Mattivi Production, Nigeria, p. 465.

Benson, N.U., 2010a. National priorities for implementing adaptation to climate in Nigeria. In: IOC-UNESCO Workshop Series for Adaptation to Climate Change in Africa. A Technical Report of IOC-UNESCO, France, p. 20.

Benson, N.U., 2010b. Nigeria'S Progress in Adapting to Climate Change on Oceans and Coasts. A Technical Report Prepared for the Intergovernmental Oceanographic Committee-UNESCO 50th Anniversary.

Benson, N.U., Adedapo, A.E., Eritobor, A.L., Udosen, E.D., 2015. Total dissolved inorganic carbon and physicochemical characteristics of surface microlayer and upper mixed layer water from Lagos Lagoon, Nigeria. Glob. NEST J. 17 (2), 334-343.

Benson, N.U., Essien, J.P., Asuquo, F.E., Eritobor, A.L., 2014. Occurrence and distribution of polycyclic aromatic hydrocarbons in surface microlayer and subsurface seawater of lagos lagoon, Nigeria. Environ. Monit. Assess. 186, 5519-5529. http://dx.doi.org/10.1007/s10661-014-3800-z.

Benson, N.U., Fred-Ahmadu, O.H., 2020. Occurrence and distribution of microplastics-sorbed phthalic acid esters (PAEs) in coastal psammitic sediments of tropical Atlantic Ocean, Gulf of Guinea. Sci. Total Environ. 730, 139013. http://dx.doi.org/10.1016/j.scitotenv.2020.139013.

Bosker, T., Guaita, L., Behrens, P., 2018. Microplastic pollution on caribbean beaches in the lesser antilles. Mar. Pollut. Bull. 133, 442-447. http://dx.doi. org/10.1016/j.marpolbul.2018.05.060.

Constant, M., Kerhervé, P., Mino-Vercellio-Verollet, M., Dumontier, M., Sànchez Vidal, A., Canals, M., Heussner, S., 2019. Beached microplastics in the Northwestern Mediterranean Sea. Mar. Pollut. Bull. 142, 263-273. http://dx.doi.org/10.1016/j.marpolbul.2019.03.032.

Edo, C., Tamayo-Belda, M., Martínez-Campos, S., Martín-Betancor, K., GonzálezPleiter, M., Pulido-Reyes, G., ..., Rosal, R., 2019. Occurrence and identification of microplastics along a beach in the Biosphere Reserve of Lanzarote. Mar Pollut. Bull. 143, 220-227. http://dx.doi.org/10.1016/j.marpolbul.2019.04.061.

Fred-Ahmadu, O.H., Bhagwat, G., Oluyoye, I., Benson, N.U., Ayejuyo, O.O., Palanisami, T., 2020. Interaction of chemical contaminants with microplastics: principles and perspectives. Sci. Total Environ. 706, 135978. http://dx. doi.org/10.1016/j.scitotenv.2019.135978.

French, G.T., Awosika, L.F., Ibe, C.E., 1995. Sea level rise and Nigeria: potential impacts and consequences. J. Coast. Res. Special Issue 14, 224-242.

GESAMP Joint Group of Experts on the Scientific Aspects of Marine Environmental Protection, 2015. Sources, Fate and Effects of Microplastics in the Marine Environment: A Global Assessment. Reports and Studies GESAMP, 90, p. 96. http://dx.doi.org/10.13140/RG.2.1.3803.7925.

Holmes, L.A., 2013. Interactions of trace metals with plastic production pellets in the marine environment. Retrieved from https://pearl.plymouth.ac.uk/ handle/10026.1/1593.

Hüffer, T., Weniger, A.-K., Hofmann, T., 2018. Sorption of organic compounds by aged polystyrene microplastic particles. Environ. Pollut. 236, 218-225. http://dx.doi.org/10.1016/j.envpol.2018.01.022.

Jung, M.R., Horgen, F.D., Orski, S.V.C.V.R., Beers, K.L., Balazs, G.H., ., Lynch, J.M., 2018. Validation of ATR FT-ir to identify polymers of plastic marine debris, including those ingested by marine organisms. Mar. Pollut. Bull. 127, 704-716. http://dx.doi.org/10.1016/j.marpolbul.2017.12.061.

Karthik, R., Robin, R.S., Purvaja, R., Ganguly, D., Anandavelu, I., Raghuraman, R., ., Ramesh, R., 2018. Microplastics along the beaches of southeast coast of India. Sci. Total Environ. 645, 1388-1399. http://dx.doi.org/10.1016/j. scitotenv.2018.07.242.

Korez, Š., Gutow, L., Saborowski, R., 2019. Microplastics at the strandlines of Slovenian beaches. Mar. Pollut. Bull. 145, 334-342. http://dx.doi.org/10.1016/ J.MARPOLBUL.2019.05.054.

Kunz, A., Walther, B.A., Löwemark, L., Lee, Y.-C., 2016. Distribution and quantity of microplastic on sandy beaches along the northern coast of Taiwan. Mar Pollut. Bull. 111 (1-2), 126-135. http://dx.doi.org/10.1016/j.marpolbul.2016. 07.022 .

Law, K.L., Thompson, R.C., 2014. Microplastics in the seas. Science 345 (6193), 144-145. http://dx.doi.org/10.1126/science.1254065. 
Leslie, H., Vethaak, D., 2014. Macro, micro and nanoplastic pollution in the aquatic and terrestrial environments: Sources, fate, exposure and ecological and toxicological impacts. In: SETAC Europe 24th Annual Meeting.

Li, R.L., Liang, J., Gong, Z.B., Zhang, N.N., Duan, H.L., 2017. Occurrence, spatial distribution, historical trend and ecological risk of phthalate esters in the jiulong river, southeast China. Sci. Total Environ. 580, 388-397.

Lithner, D., Larsson, Å., Dave, G., 2011. Environmental and health hazard ranking and assessment of plastic polymers based on chemical composition. Sci. Total Environ. 409 (18), 3309-3324. http://dx.doi.org/10.1016/j.scitotenv.2011.04. 038.

Martinelli Filho, J.E., Monteiro, R.C.P., 2019. Widespread microplastics distribution at an amazon macrotidal sandy beach. Mar. Pollut. Bull. 145, 219-223. http://dx.doi.org/10.1016/j.marpolbul.2019.05.049.

Naji, A., Esmaili, Z., Khan, F.R., 2017. Plastic debris and microplastics along the beaches of the Strait of Hormuz, Persian Gulf. Mar. Pollut. Bull. 114 (2), 1057-1062. http://dx.doi.org/10.1016/j.marpolbul.2016.11.032.

National Oceanic and Atmospheric Administration, N., 2016. Glossary NOAA shoreline. from https://shoreline.noaa.gov/glossary.html (Retrieved November 15, 2019).

Ogata, Y., Takada, H., Mizukawa, K., Hirai, H., Iwasa, S., Endo, S., ., Thompson, R.C., 2009. International pellet watch: Global monitoring of persistent organic pollutants (POPs) in coastal waters. 1. Initial phase data on PCBs, DDTs, and HCHs. Mar. Pollut. Bull. 58 (10), 1437-1446. http://dx.doi.org/10.1016/j. marpolbul.2009.06.014.

Ramirez, M.M.B., Caamal, R.D., von Osten, J.R., 2019. Occurrence and seasonal distribution of microplastics and phthalates in sediments from the urban channel of the Ria and coast of Campeche, Mexico. Sci. Total Environ. 672, 97-105. http://dx.doi.org/10.1016/j.scitotenv.2019.03.472.

Rochman, C.M., 2013. Plastics and priority pollutants: A multiple stressor in aquatic habitats. Environ. Sci. Technol. (47), 2439-2440.
Smith, J.E., 1959. Zoology in Nigeria: Ecology of Lagos lagoon. Nature 183, 295-296. http://dx.doi.org/10.1038/183295a0.

Thompson, R., 2016. Sources, fate and effects of microplastics in the marine environment ( 2012-2018). Insights from the GESAMP report(s) on microplastics, http://www.gesamp.org/publications/report-of-the-43rd-session.

Thompson, R.C., Olson, Y., Mitchell, R.P., Davis, A., Rowland, S.J., John, A.W.G., ., Russell, A.E., 2004. Lost at sea: Where is all the plastic?. Science 304 (5672), 838. http://dx.doi.org/10.1126/science.1094559.

Vethaak, A.D., Leslie, H.A., 2016. Plastic debris is a human health issue. Environ. Sci. Technol. 50 (13), 6825-6826. http://dx.doi.org/10.1021/acs.est.6b02569.

Xu, P., Peng, G., Su, L., Gao, Y., Gao, L., Li, D., 2018a. Microplastic risk assessment in surface waters: A case study in the Changjiang Estuary, China. Mar. Pollut. Bull. 133, 647-654. http://dx.doi.org/10.1016/j.marpolbul.2018.06.020.

Xu, P., Peng, G., Su, L., Gao, Y., Gao, L., Li, D., 2018b. Microplastic risk assessment in surface waters: A case study in the Changjiang Estuary, China. Mar. Pollut. Bull. 133, 647-654. http://dx.doi.org/10.1016/j.marpolbul.2018.06.020.

Young, A.M., Elliott, J.A., 2016. Characterization of microplastic and mesoplastic debris in sediments from Kamilo Beach and Kahuku Beach, Hawai'i. Mar. Pollut. Bull. 113 (1-2), 477-482. http://dx.doi.org/10.1016/j.marpolbulL.2016. 11.009.

Zhang, Q., Song, J., Li, X., Peng, Q., Yuan, H., Li, N., Duan, L., Ma, J., 2019. Concentrations and distribution of phthalate esters in the seamount area of the Tropical Western Pacific Ocean. Mar. Pollut. Bull. 140, 107-115. http://dx.doi.org/10.1016/j.marpolbul.2019.01.015.

Zhang, H., Zhou, Q., Xie, Z., Zhou, Y., Tu, C., Fu, C., Mi, W., Ebinghaus, R., Christie, P., Luo, Y., 2018. Occurrences of organophosphorus esters and phthalates in the microplastics from the coastal beaches in north China. Sci. Total Environ. 616-617, 1505-1512. http://dx.doi.org/10.1016/j.scitotenv. 2017.10.16. 